\title{
A Review of Horwitz, Horwitz and Cope's Theory of Foreign Language Anxiety and the Challenges to the Theory
}

\author{
TRAN Thi Thu Trang \\ School of Education, Faculty of Social Sciences and Behavioural Studies \\ The University of Queensland, Australia \\ E-mail: tranghce@gmail.com
}

$\begin{array}{lcc}\text { Received: July 19, } 2011 & \text { Accepted: December 30, } 2011 & \text { Published: January 1, } 2012 \\ \text { doi:10.5539/elt.v5n1p69 } & \text { URL: http://dx.doi.org/10.5539/elt.v5n1p69 }\end{array}$

This study was funded by Endeavour Postgraduate Awards.

\begin{abstract}
Language anxiety has become a great concern in second and foreign language learning research over the last three decades, and is a topic that triggers significant differences of opinions. As the first theory that emphasises the specific nature of foreign language anxiety, Horwitz, Horwitz, and Cope's theory of foreign language anxiety has been used in quite a number of studies in the field. This paper reviews the theory and discusses the criticisms that other researchers have put forward it with an aim to provide further understanding of the theory for those who are interested in involving foreign language anxiety in their research.
\end{abstract}

Keywords: Language anxiety, Anxiety research, Theoretical framework, Foreign Language Classroom Anxiety Scale

\section{Introduction}

Research has shown that anxiety is not uncommon in almost all disciplines of learning. Recently, Cassady (2010) introduced the term academic anxiety as "a unifying formulation for the collection of anxieties learners experience while in schools" (p. 1). While it seems that there is some commonality in terms of the nature and consequences of anxiety, the type of anxiety triggered in and suffered by learners from each specific discipline is, to a certain extent, unique to that specific discipline. Foreign language anxiety (FLA) is one such unique type of anxiety. There is a considerable body of research indicating that foreign language anxiety is not merely an abstract construct studied by theorists or by researchers under laboratory on induced-anxiety conditions, but a reality for many students (e.g., Casado \& Dereshiwsky, 2001; Coryell \& Clark, 2009; Kostić-Bobanović, 2009; Liu, 2006; Liu \& Jackson, 2008; MacIntyre \& Gardner, 1994a; Tallon, 2009; Von Wörde, 2003).

In terms of definition, several researchers have offered definitions of foreign language anxiety. Clement (1980) defined foreign language anxiety as a complex construct that deals with learners' psychology in terms of their feelings, self-esteem, and self-confidence. Emphasising the distinctive feature of FLA, Young (1992) defined it as a complicated psychological phenomenon peculiar to language learning. More specifically, MacIntyre and Gardner (1994b) defined FLA as the feeling of tension and apprehension specifically associated with second or foreign language contexts, including speaking, listening, and learning, or the worry and negative emotional reaction arousal when learning or using a second or foreign language (MacIntyre, 1999). Similarly, Zhang (2001) defined anxiety as the psychological tension that the learner goes through in performing a learning task. These definitions, in fact, are built around the claim made by Horwitz, Horwitz and Cope (1986) that FLA is "a phenomenon related to but distinguishable from other specific anxieties" (p. 129). Horwitz, Horwitz and Cope were the first to conceptualise FLA as a unique type of anxiety specific to foreign language learning. Their theoretical model of FLA plays a vital role in language anxiety research, which has made them influential researchers in this area.

\section{Horwitz, Horwitz and Cope's Theory of Foreign Language Anxiety}

In their well known article, Horwitz, Horwitz and Cope (1986) defined FLA as "a distinct complex construct of self-perceptions, beliefs, feelings, and behaviours related to classroom language learning arising from the uniqueness of language learning process" (p. 128).

Up to the time the theory was introduced, it was understood that anxiety research had been unable to establish a 
clear-cut relationship between anxiety and foreign language achievement (see review by Scovel, 1978). Horwitz, Horwitz and Cope thus suggested that one reason accounting for this failure was the lack of anxiety measures specific to foreign language learning. Only one instrument, a five-item scale designed by Gardner, Clement, Smythe, and Smythe (1979), was relevant to FLA, but it was restricted in scope.

Based on their clinical experience with foreign language students in university classes during their teaching process, and feedback received from 30 students attending a support group for language learning, Horwitz, Horwitz and Cope suggested that foreign language anxiety should be viewed as a situation-specific anxiety arising from the uniqueness of the formal learning of a foreign language, not just a case of general classroom anxiety being transferred to foreign language learning. According to Horwitz et al., no other fields of study implicate self-concept and self-expression to the same degree as foreign language study. This feature makes the anxiety caused by foreign language learning distinctive from other academic anxieties. It is possible that students with general anxiety are likely to experience FLA; however, it is not uncommon to find those who are very good at other subjects frustrated in learning a foreign language. Therefore, there must be something unique to the language learning experience that makes some students anxious.

Although Horwitz et al.'s theory evolved mainly from clinical data and anecdotal evidence, a large number of studies conducted subsequently adopted their theoretical model, thus supplying evidence to validate their theory of anxiety particular to language learning. MacIntyre and Gardner (1989), for example, used nine anxiety scales, including French Class Anxiety Scale, English Class Anxiety Scale, Mathematics Anxiety Scale, French Use Anxiety Scale, Trait Anxiety Scale, Computer Anxiety Scale, State Anxiety Scale, Test Anxiety Scale, Audience Anxiety Scale to examine the relationship between the dimensions of anxiety and the various measures of learning and production, including oral and written scores. Factor analysis of the scales and correlational analysis between the anxiety scales and achievement measures indicated that foreign language anxiety is separable from general anxiety, and a clear relationship was found to exist between FLA and foreign language proficiency while only a weak relationship was found between general anxiety and foreign language proficiency. Chen and Chang (2004) also found that neither academic learning history nor test characteristics were variables predictive of foreign language anxiety, which can be interpreted to mean that foreign language anxiety is a form of situation-specific anxiety that is uniquely related to foreign language learning experience. These results supported Horwitz et al.'s theory of a unique type of anxiety that is specific to foreign language learning. More justification of this conclusion requires a look into the development of foreign language anxiety research before and after the introduction of Horwitz et al.'s theory of anxiety specific to foreign language learning.

In the 1970s, anxiety research mainly used the state-trait anxiety viewpoint to investigate the role of anxiety in language learning. This approach posited language anxiety as a transfer of other more general types of anxiety. For example, test-anxious people may feel anxious when learning a language because they feel constantly tested, or shy people may feel uncomfortable because of the demands of communicating publicly. Early studies adopting this approach produced conflicting results about the effects of anxiety on achievement and performance. Specifically, Tucker, Hamayan, and Genesee (1976) found significant negative correlations between language anxiety and one of four French performance indices, i.e., Test de Rendement en français, but not three other indicators. i.e., Reading Comprehension, Listening Comprehension, and Oral Production; whereas, Young (1986) found no relationship between state anxiety and oral proficiency in French, German and Spanish when students' ability was controlled. Other studies reported contradictory results. For example, in a study of university students in approximately one third of the courses offered in beginning French, German, and Spanish, Chastain (1975) concurrently found positive, negative, and near zero correlations between anxiety and French, German and Spanish second language learning. While finding a negative correlation between French students' scores on tests and anxiety, Chastain also discovered a positive correlation between anxiety and the scores of German and Spanish students.

Horwitz, Horwitz, and Cope's explanation for the inconsistency of the research findings was similar to that of Scovel (1978), who recognised conflicting findings in the earlier anxiety research and attributed them to the problems of construct ambiguity, confusing definitions of anxiety, and lack of proper language anxiety measures. Scovel thus suggested that researchers should be specific about the type of anxiety to be studied. This view was supported by Gardner (1985), who argued that the measures directly concerned with foreign language anxiety were more appropriate for studying foreign language anxiety than general anxiety measures. According to Gardner, not all forms of anxiety would influence second or foreign language learning, but "a construct of anxiety which is not general but instead is specific to the language acquisition context is related to second language achievement" (p.34). Other researchers also expressed their consensus by stating that the variety of anxiety types made it possible that the anxiety being studied was not the anxiety specific to language learning (MacIntyre, 1999; Young, 1994). Most recently, Horwitz (2010) reported a foreign and second language anxiety research timeline, in which she once again 
postulated that one of the reasons for such confusing results was the multi-faceted conceptualisation of anxiety which differentiates a number of types of anxiety, including trait anxiety, state anxiety, achievement anxiety, and facilitating-debilitating anxiety.

In their theory, Horwitz, Horwitz and Cope (1986) acknowledged the uniqueness of foreign language anxiety and introduced the Foreign Language Classroom Anxiety Scale (FLCAS) as an instrument to measure anxiety levels as evidenced by negative performance expectancies and social comparisons, psychophysiological symptoms, and avoidance behaviours. The FLCAS consists of 33 statements with significant part-whole correlations with the total scale, aiming to assess communication apprehension, test anxiety and fear of negative evaluation associated with language anxiety. Each item on the FLCAS is rated on a five-point Likert scale ranging from 1 (strongly agree) to 5 (strongly disagree). Total scores of the scale range from 33 to 165 with lower scores indicate higher levels of anxiety. Twenty-four of the items are positively worded, and nine of the items are negatively worded.

Horwitz et al.'s theory of foreign language anxiety has been widely accepted with subsequent research acknowledging the uniqueness of foreign language anxiety and providing evidence that the FLCAS is a reliable tool. Since then, "the concept of anxiety in second language acquisition has achieved the status of a precise technical notion" (Young, 1994, p.3) with more consistent research findings of the negative effects of language anxiety on achievement and performance (e.g., Djigunovic, 2006; Horwitz, 1991; Ito, 2008; MacIntyre, 1988; MacIntyre \& Gardner, 1989, 1991a; Tallon, 2009).

Although Horwitz et al.'s theory has been widely used, some issues have triggered rather heated debates.

\section{Challenges to Horwitz, Horwitz and Cope's Theory of Foreign Language Anxiety}

Four points in Horwitz et al.'s theory have been challenged: (i) the direction of the causal relationship between FLA and language learning difficulties; (ii) the important role of FLA; (iii) the components of FLA; and (iv) the validity of the FLCAS.

First, opposing views have been found in terms of the direction of the causal relationship between FLA and language learning difficulties. While Horwitz et al. postulated the detrimental effects of FLA on language learning, some other researchers considered it a consequence rather than a cause (Argaman \& Abu-Rabia, 2002; Ganschow et al., 1994; Sparks \& Ganschow, 1991, 1995). According to Sparks and Ganschow (1995), "one cannot discuss anxiety without inferring a cause" (p. 236). Although they agreed that anxiety could hinder learning and students might experience anxiety in learning a foreign language, it was their view that anxiety is more likely to be a consequence rather than a cause of poor achievement in foreign language learning. In supporting Sparks and Ganschow's hypothesis, Argaman and Abu-Rabia (2002) examined the influence of language anxiety on achievement in English writing and reading comprehension tasks and found a significant relationship between language anxiety and both reading and writing skills. However, they argued that language anxiety might not be a cause of failure in learning a foreign language, but a consequence.

In support of Horwitz et al.'s position, MacIntyre (1995b) argued against Sparks and Ganschow, indicating that anxiety arousal could act as a causal agent in creating individual differences in second or foreign language learning. He used the example of the student who knows the material but "freezes up" on a test to argue that anxiety is more likely to be a cause rather than a consequence of poor performance. His view was further supported by Horwitz (2000), who argued that Sparks and Ganschow's theory could not explain why advanced and successful students also reported anxious reactions. Sparks and Ganschow (1995) have commented that these differing views are a chicken and egg phenomenon. That is, does the language difficulty cause anxiety or does anxiety cause the language difficulty? In fact, the two sides have not totally rejected each other's perspective. While arguing that anxiety both causes students to learn less and makes students unable to demonstrate the information that they have learned, MacIntyre (1995a) also recognised the cyclical relation between anxiety and task performance. He pointed out that students' anxiety level might increase even more as students experience more failure.

It seems that the answer to the question whether language difficulty causes anxiety or anxiety causes language difficulty may differ between situations. Sparks and Ganschow are right to point out that anxiety is likely to result from certain situations with a possible reason being language difficulty in the case of language learning; however, the fact is that even good students experience FLA regardless of its frequency. Therefore, it cannot be denied that anxiety is likely to be both a cause and an effect of language difficulty. A point made by Horwitz (2001) about this question seems to be logical, that is, "it is easy [italics added] to conceptualise FLA as a result of poor language learning ability ... the challenge is to determine the extent to which anxiety is a cause rather than a result of poor language learning" (p. 118).

Second, while Horwitz et al. have attributed a very important affective role to foreign language anxiety, some 
researchers consider it as either being independent of or having little effect on foreign language achievement. Sparks and Ganschow (1991, 1993a, 1993b, 2007) have cast doubt on the importance attributed to FLA in foreign language learning, arguing that it is not likely to be a primary cause of problems with foreign language learning. They questioned the claims made by Horwitz et al. about the importance of anxiety and argued that studying anxiety does not add much to the understanding of language achievement. Instead, they advocated their Linguistic Coding Differences Hypothesis (LCDH) as an alternative to account for poor foreign language learning achievement (see Sparks \& Ganschow, 1991; Sparks, Ganschow, \& Pohlman, 1989). According to Sparks and Ganschow (1991, 1995), the possibility of a confounding interaction between anxiety and receptive/expressive language skills (such as listening, speaking, and audio memory) in the foreign language learning might exist, and that first language learning deficits are the primary source of poor achievement. Argaman and Abu-Rabia (2002) supported this view, arguing that "if students with high language anxiety obtained significantly low grades in every foreign-language skill, the real problem may not be the anxiety but a lack of ability in the foreign language arising from a totally different origin" (p. 157). Spieldmann and Radnofsky (2001) have also had doubts about the importance of foreign language anxiety in language learning, suggesting that anxiety research should shift the focus from anxiety to tension.

Despite these opposing views, it is clear that a large body of research on the effects of foreign language anxiety has provided strong evidence about the detrimental effects of FLA on language learning. Based on these research findings, one may agree with MacIntyre (1995a) that "the effects of anxiety may be more complex than has been implied by Sparks and Ganschow" (p. 96). Besides, it should be important to note that different disciplines may offer competing explanations for difficulties that foreign language learners encounter (Young, 1995). In this case, MacIntyre is a cognitive psychologist, therefore he emphasises the need to examine the role of cognitive and affective variables to understand how individuals learn a foreign or second language; meanwhile, Sparks and Ganschow are learning-disability specialists, so they suggest that an examination of language aptitude alone can offer explanations for much of the success or failure in language learning. Although their interpretations and approaches to the same issue are different, it does not necessarily mean that one position excludes the other. It should also be noted that a few studies have found no significant correlation between first language learning history and foreign language anxiety; that is, first language learning history is not the best predictor of foreign language anxiety (Chen \& Chang, 2004; MacIntyre \& Gardner, 1989, 1994a), which does not support Sparks and Ganschow's LCDH. As Horwitz (2001) has stated, "in addition to contributing to our understanding of second language achievement, language anxiety is fundamental to our understanding of how learners approach language learning, their expectations for success or failure, and ultimately why they continue or discontinue study" (p.122). If we accept these arguments as being true, the important role of anxiety in foreign language learning becomes undisputable.

The third challenge is related to the components of FLA. Horwitz et al. have integrated three related anxieties in their conceptualisation of foreign language anxiety, including communication apprehension, test anxiety, and fear of negative evaluation. However, while communication apprehension and fear of negative evaluation are closely related to FLA, test anxiety is likely to be a general anxiety problem rather than being specific to foreign language learning. This has been justified in some studies. In examining the relationship between test anxiety, general anxiety and communicative anxiety, MacIntyre (1989) found that test anxiety contributed to the general anxiety factor and not to the communicative anxiety factor, thus suggesting that test anxiety is a general problem rather than being specific to the foreign language classroom. Using factor analysis to detect the underlying structure of the FLCAS's thirty-three statements, Aida (1994) also reported that the findings did not support Horwitz's claim for the inclusion of test anxiety as a component of FLA. These findings have led Horwitz (2010) to clarify her position that FLA is related to communication apprehension, fear of negative evaluation and test anxiety rather than being composed of them as "misinterpreted" by many researchers (p. 158).

In addition, Sparks and Ganschow $(1991,1996,2007)$ have questioned the validity of the FLCAS and claimed that it measures language skills rather than anxiety levels. According to Sparks and Ganschow, 60 percent of the items (20/33) involve comfort level with expressive or receptive language, 15 percent of the items (5/33) involve verbal memory for language, 12 percent of the items (4/33) involve difficulty with reading and writing, and 12 percent of the items (4/33) involve speed of language processing. They have also criticised the FLCAS which excludes native language skills or foreign language aptitude. Other researchers such as Aida (1994) and Rodríguez and Abreu (2003) have posited that the FLCAS appears to measure anxiety primarily related to speaking situations. To some extent, these views may be true; however, it is also true that with the same data set, each researcher may have his or her own way of interpreting the data, which does not necessarily mean that way is right and the other ways are wrong. In addition, it is evident that since the introduction of Horwitz et al.'s FLCAS as an instrument to measure anxiety levels, the FLCAS has been widely used in language anxiety research, and the problem of inconsistent research 
findings has been considerably solved, which has strengthened its reliability.

Despite the above challenges, it has become clear that the distinctiveness and complexity of FLA differentiate it from other anxieties. Foreign or second language learning has "more potential for students to embarrass themselves, to frustrate their self-expression, and to challenge their self-esteem and sense of identity than almost any other learning activities" (MacIntyre, 1999, p. 33); therefore, anxiety derived from foreign or second language learning is associated with, but distinctive from other types of anxiety. As such, consensus has been reached that foreign language anxiety is a unique type of anxiety, not a transfer of other forms of anxiety.

\section{Conclusion}

Horwitz, Horwitz, and Cope's theory of foreign language anxiety has played a vital role in language anxiety research with a large number of studies using it as the theoretical framework. However, it does not necessarily mean that the theory is perfect, as "the most accepted working hypotheses themselves may need revising" (Spielmann \& Radnofsky, 2001, p. 261). With its complexity and controversy, it is likely that foreign language anxiety has been and will continue to be a key area of research interest.

\section{References}

Aida, Y. (1994). Examination of Horwitz, Horwitz, and Cope's construct of foreign language anxiety: The case of students of Japanese. The Modern Language Journal, 78(2), 155-168. http://dx.doi.org/10.2307/329005

Argaman, O., \& Abu-Rabia, S. (2002). The influence of language anxiety on English reading and writing tasks among native Hebrew speakers. Language, Culture and Curriculum, 15(2), 143-160. http://dx.doi.org/10.1080/07908310208666640

Casado, M. A., \& Dereshiwsky, M. I. (2001). Foreign language anxiety of university students. College Student Journal, 35(4), 539-551

Cassady, J. C. (Ed.). (2010). Anxiety in schools: The causes, consequences, and solutions for academic anxieties. New York: Peter Lang.

Chastain, K. (1975). Affective and ability factors in second language acquisition. Language Learning, 25(1), 153-161. http://dx.doi.org/10.1111/j.1467-1770.1975.tb00115.x

Chen, T. Y., \& Chang, G. B. Y. (2004). The relationship between foreign language anxiety and learning difficulties. Foreign Language Annals, 37(2), 279-289. http://dx.doi.org/10.1111/j.1944-9720.2004.tb02200.x

Clément, R. (1980). Ethnicity, contact, and communicative competence in a second language. In H. Giles, W. P. Robinson, \& P. M. Smith (Eds.), Language: Social psychological perspectives. Oxford, United Kingdom: Pergamon Press. pp. 147-154

Coryell, J. E., \& Clark, M. C. (2009). One right way, intercultural participation, and language learning anxiety: A qualitative analysis of adult online heritage and nonheritage language learners. Foreign Language Annals, 42(3), 483-504. http://dx.doi.org/10.1111/j.1944-9720.2009.01037.x

Djigunovic, J. M. (2006). Language anxiety and language processing. In S. H. FosterCohen, M. M. Krajnovic, \& J. M. Djigunovic (Eds.), EUROSLA Yearbook, Vol. 6, 191-212

Ganschow, L., Sparks, R. L., Anderson, R., Javorshy, J., Skinner, S., \& Jon, P. (1994). Differences in language performance among high-, average-, and low-anxious college foreign language learners. The Modern Language Journal, 78(1), 41-55. http://dx.doi.org/10.2307/329251

Gardner, R. C. (1985). Social psychology and second language learning. The role of attitudes and motivation. London: Edward Arnold.

Gardner, R. C., Clément, R., Smythe, P. C., \& Smythe, C. C. (1979). Attitudes and motivation test battery, revised manual. Research Bulletin, 15

Horwitz, E. K. (1991). Preliminary evidence for the reliability and validity of a foreign language anxiety scale. In E. K. Horwitz, \& D. J. Young (Eds.), Language anxiety: From theory and research to classroom implications. Englewood Cliffs, New Jersey: Prentice Hall. pp. 37-39

Horwitz, E. K. (2000). Horwitz comments: It ain't over 'til it's over: On foreign language anxiety, first language deficits, and the confounding of variables. The Modern Language Journal, 84(2), 256-259. http://dx.doi.org/10.1111/0026-7902.00067

Horwitz, E. K. (2001). Language anxiety and achievement. Annual Review of Applied Linguistics, 21, 112-126. http://dx.doi.org/10.1017/S0267190501000071 
Horwitz, E. K. (2010). Foreign and second language anxiety. Language Teaching, 43, 154-167. http://dx.doi.org/10.1017/S026144480999036X

Horwitz, E. K., Horwitz, M. B., \& Cope, J. A. (1986). Foreign language classroom anxiety. The Modern Language Journal, 70(2), 125-132. http://dx.doi.org/10.2307/327317

Kostić-Bobanović, M. (2009). Foreign language anxiety of university students. Ekonomska Istrazivanja-Economic Research, 22(3), 47-54

Liu, M. (2006). Anxiety in EFL classrooms: Causes and consequences. TESL Reporter, 39(1), 13-32.

Liu, M., \& Jackson, J. (2008). An exploration of Chinese EFL learners' unwillingness to communicate and foreign language anxiety. The Modern Language Journal, 92(1), 71-86. http://dx.doi.org/10.1111/j.1540-4781.2008.00687.x

M. (2009). Foreign language anxiety of university students. Ekonomska Istrazivanja-Economic Research, 22(3), 47-54

MacIntyre, P. D. (1988). The measurement of anxiety and applications to second language learning: An annotated bibliography. Research Bulletin, 672

MacIntyre, P. D. (1995a). How does anxiety affect second language learning? A reply to Sparks and Ganschow. The Modern Language Journal, 79(1), 90-99. http://dx.doi.org/10.2307/329395

MacIntyre, P. D. (1995b). On seeing the forest and the trees: A rejoinder to Sparks and Ganschow. The Modern Language Journal, 79(2), 245-248. http://dx.doi.org/10.2307/329623

MacIntyre, P. D. (1999). Language anxiety: A review of the research for language teachers. In D. J. Young (Ed.), Affect in foreign language and second language learning: A practical guide to creating a low-anxiety classroom atmosphere. Boston: McGraw-Hill. pp. 24-45

MacIntyre, P. D., \& Gardner, R. C. (1989). Anxiety and second-language learning: Toward a theoretical clarification. Language Learning, 39(2), 251-275. http://dx.doi.org/10.1111/j.1467-1770.1989.tb00423.x

MacIntyre, P. D., \& Gardner, R. C. (1991a). Methods and results in the study of anxiety and language learning: A review of the literature. Language Learning, 41(1), 85-117. http://dx.doi.org/10.1111/j.1467-1770.1991.tb00677.x

MacIntyre, P. D., \& Gardner, R. C. (1994a). The effects of induced anxiety on three stages of cognitive processing in computerised vocabulary learning. Studies in Second Language Acquisition, 16, 1-17. http://dx.doi.org/10.1017/S0272263100012560

MacIntyre, P. D., \& Gardner, R. C. (1994b). The subtle effects of language anxiety on cognitive processing in the second language. Language Learning, 44(2), 283-305. http://dx.doi.org/10.1111/j.1467-1770.1994.tb01103.x

Rodríguez, M., \& Abreu, O. (2003). The stability of general foreign language classroom anxiety across English and French. The Modern Language Journal, 87(3), 365-374

Scovel, T. (1978). The effect of affect on foreign language learning: A review of the anxiety research. Language Learning, 28(1), 129-142. http://dx.doi.org/10.1111/j.1467-1770.1978.tb00309.x

Sparks, R. L., \& Ganschow, L. (1991). Foreign language learning differences: Affective or native language aptitude differences? The Modern Language Journal, 75(1), 3-16. http://dx.doi.org/10.2307/329830

Sparks, R. L., \& Ganschow, L. (1993a). The impact of native language learning problems on foreign language learning: Case study illustrations of the linguistic coding deficit hypothesis. The Modern Language Journal, 77, 58-74. http://dx.doi.org/10.2307/329559

Sparks, R. L., \& Ganschow, L. (1993b). Searching for the cognitive locus of foreign language learning difficulties: Linking first and second language learning. The Modern Language Journal, 77, 289-302. http://dx.doi.org/10.2307/329098

Sparks, R. L., \& Ganschow, L. (1995). A strong inference approach to causal factors in foreign language learning: A response to MacIntyre. The Modern Language Journal, 79(2), 235-244. http://dx.doi.org/10.2307/329622

Sparks, R. L., \& Ganschow, L. (1996). Teachers' perceptions of students' foreign language academic skills and affective characteristics. The Journal of Educational Research, 89(3), 172-185. http://dx.doi.org/10.1080/00220671.1996.9941323

Sparks, R. L., \& Ganschow, L. (2007). Is the foreign language classroom anxiety scale measuring anxiety or language skills? Foreign Language Annals, 40(2), 260-287. http://dx.doi.org/10.1111/j.1944-9720.2007.tb03201.x

Sparks, R. L., Ganschow, L., \& Pohlman, J. (1989). Linguistic coding deficits in foreign language learners. Annals 
of Dyslexia, 39, 179-195. http://dx.doi.org/10.1007/BF02656908

Spielmann, G., \& Radnofsky, M. L. (2001). Learning language under tension: New directions from a qualitative study. The Modern Language Journal, 85(2), 259-278. http://dx.doi.org/10.1111/0026-7902.00108

Tallon, M. (2009). Foreign language anxiety and heritage students of Spanish: A quantitative study. Foreign Language Annals, 42(1), 112-137. http://dx.doi.org/10.1111/j.1944-9720.2009.01011.x

Tucker, R., Hamayan, E., \& Genesee, F. H. (1976). Affective, cognitive, and social factors in second language acquisition. Canadian Modern Language Review, 32, 214-216

Von Wörde, R. A. (2003). Students' perspectives on foreign language anxiety. Inquiry, 8(1). [Online] Available: http://www.vccaedu.org/inquiry/inquiry-spring2003/i-81-worde.html

Young, D. J. (1986). The relationship between anxiety and foreign language oral proficiency ratings. Foreign Language Annals, 19, 439-445. http://dx.doi.org/10.1111/j.1944-9720.1986.tb01032.x

Young, D. J. (1992). Language anxiety from the foreign language specialist's perspective: Interviews with Krashen, Omaggio Hadley, Terrell, and Rardin. Foreign Language Annals, 25(2), 157-172. http://dx.doi.org/10.1111/j.1944-9720.1992.tb00524.x

Young, D. J. (1994). New directions in language anxiety research. In C. A. Klee (Ed.), Faces in a crowd: The individual learner in multisection courses. Boston: Heinle and Heinle. pp. 3-46

Young, D. J. (1995). Language anxiety in second-language acquisition: Using a wider angle of focus. Georgetown University Round Table on Languages and Linguistics, 398-411

Zhang, L. J. (2001). Exploring variability in language anxiety: Two groups of PRC students learning ESL in Singapore. RELC Journal, 32(1), 73-94. http://dx.doi.org/10.1177/003368820103200105 